\title{
Lipidek és az agyérbetegség - Új lehetőségek az LDL-koleszterin-szint csökkentésére
}

\author{
Lovadi Emese dr. - Csécsei Péter dr. - Lovig Csenge dr. \\ Karádi Zsófia dr. - Szapáry László dr. \\ Pécsi Tudományegyetem, Általános Orvostudományi Kar, Klinikai Központ, Neurológiai Klinika, \\ Stroke Tanszék, Pécs
}

\begin{abstract}
A stroke világszerte a harmadik leggyakoribb halálok, a szívinfarktus és a daganatos betegségek után, funkcionális kimenetele pedig valamennyi betegség közül a legrosszabb. A koleszterin, különösen az LDL-C-szint kulcsszerepet játszik az érelmeszesedésben, a plakkok kialakulásában. Az elmúlt években bebizonyosodott, hogy az LDL-C-szint növekedésével arányosan emelkedik a cerebrovascularis betegségek incidenciája és halálozása. A statinterápia egyértelműen csökkenti a stroke-rizikót, de a más módszerekkel elért lipidszintcsökkentő kezelésnek eddig nem volt igazoltan szignifikáns hatása. A magasabb dózisú statinkezelés preventív hatása egyértelmú, ugyanakkor az ilyen dózis alkalmazása fokozott óvatosságot igényel korábbi intracerebralis vérzést elszenvedett betegeknél, és kockáztathatjuk az új keletû diabetes kialakulását is. A közelmúltban közzétett IMPROVE-IT vizsgálat elsőként igazolta, hogy a statinterápia mellé adott nem statin típusú ezetimibbel az LDL-C-szint tovább csökkenthető, ezzel párhuzamosan tovább mérséklődik a cardio- és cerebrovascularis események incidenciája, a mellékhatások számának növekedése nélkül. Ezek az eredmények újra megerősítették a minél nagyobb mértékű LDL-C-szint-csökkentés jelentőségét. A statin-ezetimib kombináció révén a célértékek elérése alacsony és közepes statindózissal is lehetséges, csökkentve ezáltal a magas dózisú statinkezelés mellékhatásainak veszélyét. Orv. Hetil., 2016, 157(52), 2059-2065.
\end{abstract}

Kulcsszavak: LDL-koleszterin, stroke, statinok, ezetimib

\section{Lipids and cerebrovascular disease - New therapeutic options in lowering LDL-cholesterol}

Stroke is the third most common cause of death worldwide following myocardial infaction and malignancies, furthermore, its functional outcome is the worst of all conditions. Cholesterol, especially LDL-cholesterol plays a key role in the formation of atherosclerotic plaques. It has been verified recently that escalating incidence and mortality of cerebrovascular diseases are proportional to increased levels of LDL-cholesterol. Statin therapy undeniably reduces the risk of stroke, however other methods for decreasing lipid levels have not been proved significantly effective. Preventive effect of high-dose statin treatment is without doubt, although administration of such high dosage might require special precautions for patients with prior intracerebral hemorrhage and it also risks development of incident diabetes. The recently published IMPROVE-IT study is the first to prove that the addition of ezetimibe as a nonstatin type drug, to statin treatment contributes to further reduction of LDL-cholesterol. The combination treatment results in additional decrease in the incidence and mortality of cerebrovascular events, without any expansion in the number or adverse effects. These results confirm the importance of any further reduction of LDL-cholesterol levels. Achieving target values with statin-ezetimibe combination allows administration of low to moderate dose of statin, which decreases risks of adverse effects related to high-dose statin therapy.

Keywords: LDL cholesterol, stroke, statins, ezetimibe

Lovadi, E., Csécsei, P., Lovig, Cs., Karádi, Zs., Szapáry, L. [Lipids and cerebrovascular disease - New therapeutic options in lowering LDL-cholesterol]. Orv. Hetil., 2016, 157(52), 2059-2065.

(Beérkezett: 2016. október 14.; elfogadva: 2016. november 10.) 


\section{Rövidítések}

AHA $=$ American Heart Association CETP $=$ koleszteril-észter transzferprotein; EAS = European Atherosclerosis Society; ESC = European Society of Cardiology; HMG-CoA = 3-hidroxi-3-metil-glutaril-koenzim A; HPS = Heart Protection Study; IMPROVE-IT = IMProved Reduction of Outcomes: Vytorin Efficacy International Trial; LDL-C = alacsony sűrűségű lipoproteinhez kötött koleszterin; MULTI GAP = Multi Goal Attainment Program; NPClLl = Niemann-Pick Cl-szerü fehérje 1; PCSK9 = proproteinkonvertáz szubtilizin/ kexin 9; SPARCL = Stroke Prevention by Aggressive Reduction in Cholesterol Levels; TIA = tranziens ischaemiás attak; TNT $=$ Treating to New Targets

A szívinfarktus és a daganatos betegségek után a stroke világszerte és Magyarországon is a harmadik leggyakoribb halálok. A három említett betegségcsoport közül a stroke funkcionális kimenetele a legrosszabb, és a felsoroltak közül tartós rokkantság legnagyobb számban agyérbetegség következtében alakul ki. A patomechanizmus alapján a cerebrovascularis betegségek döntő többségét (körülbelül $80 \%$-át) ischaemiás eredetű kórképek adják, amelyek kialakulásában a három fó tényezőt a nagy és közepes erek atheroscleroticus betegsége, a cardioembolisatio, illetve az agyi kiserek károsodása jelenti. A stroke legfontosabb, befolyásolható kockázati tényezői a dohányzás, az elhízás, az ülő életmód, a zsíranyagcsere zavara, a magas vérnyomás és a cukorbetegség. A koleszterin, különösen az LDL-koleszterin-szint kulcsszerepet játszik az érelmeszesedésben és a plakkok kialakulásában [1]. Az utóbbi évtizedek vizsgálatai alapján az emelkedett összkoleszterinszint és az LDL-koleszterin-szint a cardiovascularis betegségek független kockázati tényezője, e paraméterek szintje lineáris összefüggést mutat a koszorúérbetegség-eredetű halálozással. Az összmortalitás és a koleszterinszint közötti összefüggés azonban bonyolultabb. Két, összesen körülbelül 365 000-es populáción elvégzett hosszú távú követéses vizsgálat szerint a koleszterinszint és az általános halálozási arány közötti lineáris összefüggés csak a fiatal és középkorú betegcsoport esetén észlelhető, 50 éves kor fölött ez a korreláció már nem volt szignifikáns [2, 3]. A vizsgálatok azt mutatták, hogy ellentétben az összkoleszterinnel, az LDL-C-szint összefüggést mutat a cerebrovascularis betegségek incidenciájával és halálozásával. Így tehát az agyérbetegségek esetében nem az öszszkoleszterinszint, hanem az LDL-C-szint az egyik független rizikófaktor, és ez az összefüggés a legerősebb a nagyér arteriosclerosis eredetû ischaemiás stroke esetében $[4]$.

\section{Lipidcsökkentő kezelés a stroke megelőzésében}

Az LDL-koleszterin-szint csökkentését célzó vizsgálatok metaanalízise szerint a HMG-CoA-reduktáz inhibitorok
- a statinok - szignifikánsan csökkentik a cardio- és cerebrovascularis események kockázatát [5]. Napjainkban a legtöbb szakértő egyetért abban, hogy a statinok bevezetése forradalmasította e betegségek kezelését [6]. A statinok eredményesen csökkentik a vér LDL-koleszterin-szintjét, emellett számos vizsgálati eredmény alátámasztja LDL-koleszterin-szint-csökkentéstől független, gyulladáscsökkentő, endothelfunkció-javító, plakkstabilizáló hatásaikat is [7].

A jelenlegi ajánlások szerint minden átmeneti agyi keringészavaron (TIA) vagy ischaemiás stroke-on átesett betegnél javasolt az összkoleszterin-, HDL-C- és LDLC-, valamint a trigliceridszint meghatározása [8]. Az elsődleges stroke-prevenciót célzó vizsgálatokban a statinok a stroke kockázatát 11-40\%-kal csökkentették. A Heart Protection Study (HPS) vizsgálatba több mint 20 000, 40-80 év közötti, nagy vascularis rizikójú beteget randomizáltak, akik körében napi 40 mg simvastatin adása mellett $25 \%$-kal csökkent a stroke-rizikó, a vérzéses stroke-ok incidenciájának növekedése nélkül [9]. A 2004-ben elvégzett TNT vizsgálat is igazolta az erőteljesebb lipidszintcsökkentés hatásosságát. Nagyobb statindózis (10 mg vs. $80 \mathrm{mg}$ atorvastatin) alkalmazásával koszorúérbetegek körében további 25\%-os stroke-rizikó-csökkenést értek el, amely korrelált az LDL-C-szérumszinttel [10]. További metaanalízisek azt mutatták, hogy $1 \mathrm{mmol} / 1$ LDL-C-szint-csökkenést 20\%-os relatív stroke-rizikó-csökkenés követett [11]. A 2006-ban közzétett SPARCL vizsgálat szolgál a legtöbb közvetlen evidenciával a statinok szerepével kapcsolatban a stroke másodlagos prevenciójában. A vizsgálatba 4731, stroke-on vagy TIA-n átesett beteget vontak be, akiknél napi 80 mg atorvastatin- vs. placebokezelést alkalmaztak. Az ötéves követés után a stroke-ismétlődés relatív rizikója 16\%-kal csökkent, függetlenül a stroke altípusától, a mellékhatások megoszlása között pedig nem volt szignifikáns különbség. A SPARCL vizsgálat alcsoportelemzése szoros összefüggést mutatott ki az LDL-C-szint-csökkenés mértéke és a végpontesemények előfordulása között. Amennyiben a követés során az LDL-C-szint 1,8 mmol/l alatti szintet ért el, 28\%-kal csökkent a strokerizikó, míg 1,8 mmol/1 feletti LDL-C esetén a rizikócsökkenés már nem volt szignifikáns [12].

Az eddigi adatok alapján a statinterápia egyértelmúen csökkenti a stroke-rizikót, de a más módszerekkel (fibrátok, diéta stb.) elért lipidszintcsökkentésnek nem volt e tekintetben igazoltan szignifikáns hatása [13-15]. A közelmúltban publikált, később részletesen ismertetésre kerülő IMPROVE-IT vizsgálat igazolta először, hogy a statinterápia mellé a nem statin típusú ezetimibet adva az LDL-koleszterin-szint további csökkentése mellett tovább mérsékelhető a cardiovascularis események, köztük az ischaemiás stroke bekövetkeztének valószínúsége, a mellékhatások számának növekedése nélkül [16]. Mindezek alapján az IMPROVE-IT eredményei megerősítik az LDL-C-szint csökkentésének kulcsfontosságát a cardio- és cerebrovascularis betegségek kezelésében. 


\section{Statinok és az intracerebralis vérzés kockázata}

A legújabb, >114 000 betegszámú metaanalízis alapján a statinok nem növelték szignifikánsan az intracerebralis vérzések számát [17]. Néhány korábbi vizsgálat [18] és egy nemrégiben megjelent metaanalízis [19] azonban összefüggést talált az alacsonyabb összkoleszterin- és LDL-C-szint, valamint a fokozott haemorrhagiás strokerizikó között [20]. Bár a jelenség patomechanizmusa vitatott, több más tényező mellett ez annak a következménye lehet, hogy a koleszterin fontos építő szerepet tölt be az endothelium szintjén [21]. A statinoknak a koleszterinszint-csökkentő hatásuk mellett thrombocytaaggregáció-gátló hatást is tulajdonítanak, amely szintén hozzájárulhat az intracerebralis vérzések számának kismértékü emelkedéséhez [22]. A SPARCL vizsgálatban az intenzív statinterápia mellett szignifikánsan nőtt a vérzéses stroke-ok incidenciája, de ezt nagyban ellensúlyozta mind az összstroke-kockázat, mind az ischaemiás stroke és TIA rizikójának szignifikáns csökkenése [23]. Azoknál az idős betegeknél, akiknél a kórelőzményben intracerebralis vérzés szerepel és rosszul beállított a vérnyomásuk, az intracerebralis vérzés rizikója a dózissal egyenes arányban növekedhet, így náluk fokozott elővigyázatosság javasolt [19].

A kérdéskörrel kapcsolatos adatok tehát nem egybehangzóak, de az aktuális álláspont alapján a statinok alkalmazása nem növeli szignifikánsan a vérzéses stroke kockázatát. Az intracerebralis vérzés utáni statinkezelés indokolt lehet koszorúér-betegség vagy más területen megjelenő előrehaladott arteriosclerosis esetén is. Az utóbbi évtizedek gazdasági fejlődésével epidemiológiai változás következett be: a haemorrhagiás stroke incidenciája csökkent [24], ezzel egy időben az ischaemiás agyi történéseké nőtt, megerősítve, hogy a stroke prevenciójának döntő szempontja az ischaemiás eredetú agyérbetegségek kivédése.

\section{Statinok és a diabetes mellitus kockázata}

A randomizált, kontrollált vizsgálatok eredményei megoszlanak a statinhasználat és a diabetes mellitus incidenciája közötti összefüggés tekintetében. A legfrissebb metaanalízis 163039 beteg adatait értékelte, és intenzív statinkezelés mellett az új keletû diabetes mellitus kialakulási kockázatának 12\%-os, szignifikáns növekedését észlelte. A vizsgálatok alapján $80 \mathrm{mg}$ atorvastatin szedése mellett volt a legmagasabb a diabetes kockázata, amelyet az ekvivalens dózisú rosuvastatiné követett. A magas dózisú atorvastatin, mind a simvastatinhoz, mind az alacsony dózisú atorvastatinhoz képest szignifikánsan növelte a cukorbetegség rizikóját [25]. A jelenlegi álláspont alapján a statinkezelés cardiovascularis előnyei egyértelmûen felülmúlják az újonnan kialakuló diabetes kockázatát. Ugyanakkor a betegeket, különösen intenzív statinterápia esetén, tájékoztatni kell a lehetséges mellékhatásról és rendszeresen ellenőrizni kell cukorháztartásukat.

\section{Más lipidcsökkentő gyógyszerek a stroke prevenciójában}

A residualis cardiovascularis rizikó csökkentésére a statinterápia kiegészítéseként több nem statin szerrel végeztek vizsgálatokat. A niacinkezelés ugyan eredményesen csökkentette az LDL-C-szintet statin mellett alkalmazva, a cardiovascularis mortalitás mégsem csökkent és a szer nem bizonyult hatékonynak a stroke-rizikó csökkentésében sem, emellett komolyabb mellékhatásokat is észleltek $[14,15]$. A fibrátszármazékok eredményesen csökkentik a trigliceridszintet és emelik a HDL-C arányát, de hatékonyságuk a stroke megelőzésében nem tekinthető bizonyítottnak [13].

Az ezetimib a vékonybélsejtek szintjén csökkenti a koleszterin felszívódását, célpontja a bélhámsejtek kefeszegélyében expresszálódó NPC1L1 protein, a statinkezelés kiegészítéseként az LDL-C-szint további körülbelül 26\%-os csökkentése érhető el [26].

Korábban egyetlen randomizált, kontrollált vizsgálat sem tudta igazolni a statinhoz adott, nem statin lipidcsökkentő szerek hatékonyságát a cardiovascularis események prevenciójában. A 2014 novemberében ismertetett IMPROVE-IT (IMProved Reduction of Outcomes: Vytorin Efficacy International Trial) vizsgálat hipotézise az volt, hogy tovább csökken a cardiovascularis kockázat $10 \mathrm{mg}$ ezetimib $40 \mathrm{mg}$ simvastatinhoz való hozzáadásával és az LDL-C-szint 1,8 mmol/1 alatti szintre csökkentésével. A vizsgálatba több mint 18 000, akut coronariaszindrómás beteg került bevonásra, az átlagos követési idő hat év volt. A vizsgálat elsődleges végpontjai a cardiovascularis eredetű halál, a myocardialis infarctus, az instabil angina miatti hospitalizáció, a coronariarevascularisatio és a nem halálos kimenetelú stroke voltak. Az átlagos kiindulási LDL-C-érték 2,42 mmol/1 volt mindkét vizsgálati karban. Az első év végén a simvastatin-monoterápia mellett $1,81 \mathrm{mmol} / 1$, a kombinált kezelést kapó csoportban 1,37 mmol/1 LDL-C-átlagértékeket mértek (1. ábra). A követés során 5314 elsődleges végponteseményt regisztráltak, ami a simvastatint önmagában szedő betegek 34,7\%-ánál, míg a kombinált kezelésben részesülők 32,7\%-ánál fordult elő (esélyhányados: 0,936, 95\%-os konfidenciaintervallum: 0,89-0,99). A másodlagos végpontok között vizsgálták a bármely okból bekövetkezett halálozás, major coronariaesemények és nem halálos stroke összetett végpontját, ebben szintén szignifikáns csökkenés volt megfigyelhető (esélyhányados: 0,95, 95\%-os konfidenciaintervallum: 0,90-1,0). A harmadlagos végpontok között szerepelt az ischaemiás stroke is, amely a monoterápia mellett $4,1 \%$-ban, a kombinált kezelés mellett csak 3,4\%-ban fordult elő; ez 21\%os szignifikáns relatív rizikócsökkenést jelent (esélyhányados $0,79,95 \%$-os konfidenciaintervallum: 0,67-0,94) 


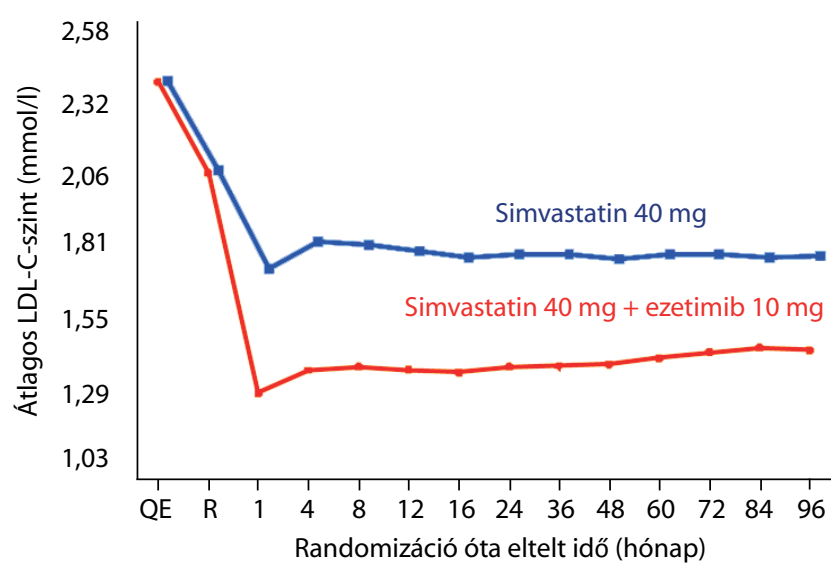

1. ábra

Átlagos LDL-C-szérumszint az IMPROVE-IT vizsgálatban egyéves követés után

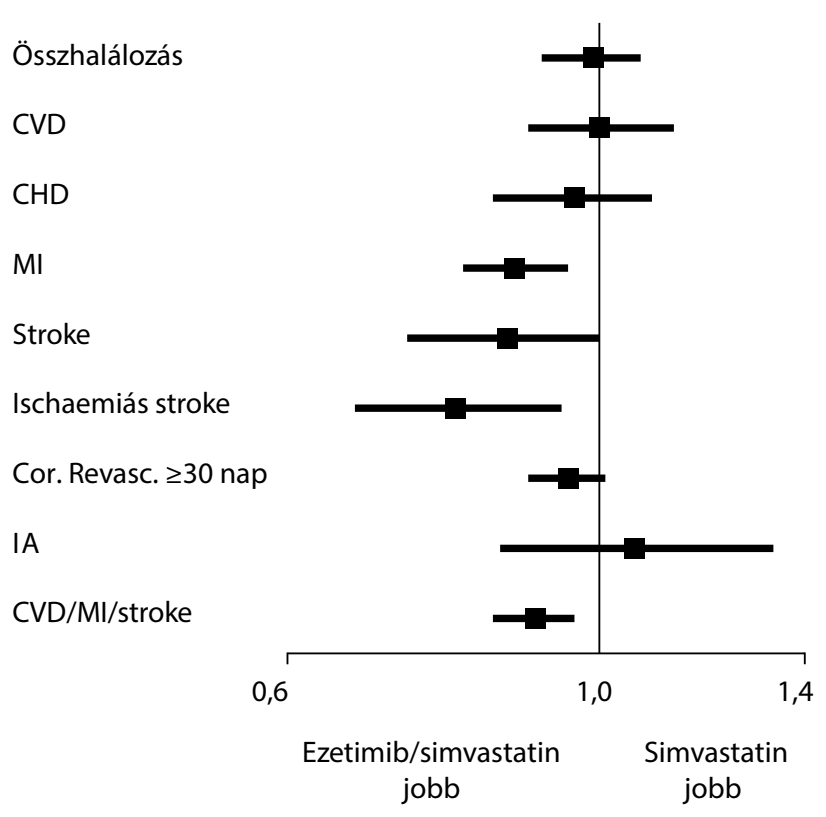

2. ábra Egyedi cardiovascularis végpontok az IMPROVE-IT vizsgálat-
ban

(2. ábra). A haemorrhagiás stroke mindkét ágon kis számban fordult elő, ebben a vonatkozásban a két csoport között nem volt szignifikáns különbség (0,6 vs. $0,8 \%, p=0,11)$. A kezelt csoportokban nem volt szignifikáns eltérés a myopathia, a rhabdomyolysis, a májenzim-emelkedés, illetve a malignus megbetegedések száma között sem [16]. Az IMPROVE-IT a robusztus betegszám és a hosszú követési idő alapján kimagasló vizsgálat, így mind a prevenció, mind a biztonságossági tényezôk tekintetében is meghatározó megállapításokra ad lehetőséget. Az IMPROVE-IT igazolta, hogy a statinhoz adott ezetimib csökkenti a cardiovascularis események számát egy viszonylag alacsony LDL-C-értékü kontrollcsoporttal szemben is [27].

Az eredmények újra megerósítették azt az elképzelést, amely szerint az LDL-C-szint csökkentése klinikailag re- leváns célkitűzés, annak további csökkentése 1,4 mmol/1 körüli szintre további kockázatcsökkenést eredményez. Ez alapján felvetődött a jelenleg érvényben lévő irányelvek módosítása is. Az intenzív, magas dózisú atorvastatinkezelés ischaemiás stroke-ot megelőző hatása egyértelmú. A kérdéses vérzéses stroke-rizikó és az új keletü diabetes szignifikáns rizikóemelkedése viszont azt támogatja, hogy a közepes dózisú statin ezetimibbel történó kiegészítése révén érjünk el hatékony és egyben biztonságos stroke-prevenciót. Az ezetimib megfelelő alternatíva lehet azoknak a betegeknek is, akik más okból nem tolerálják a magas dózisú statinkezelést.

\section{Az LDL-koleszterin-szint csökkentésének új irányvonalai}

A statinterápia hatékonyságát az LDL-C-szint csökkentésére és a cardiovascularis események kockázatának csökkentésére vonatkozóan számos korábbi vizsgálat bizonyította. Egy 2014-ben elvégzett, 170000 betegszámú metaanalízis igazolta, hogy $1 \mathrm{mmol} / \mathrm{l}$-es LDL-Cszint-csökkentés 10\%-kal csökkenti az összmortalitás relatív kockázatát, $20 \%$-kal az ischaemiás stroke relatív kockázatát [11]. Az intenzív statinterápia (>50\% LDLC-szint-csökkentés) még további 15\%-kal csökkentette a cardiovascularis események relatív rizikóját [28]. Ezek az eredmények is megerősítik, hogy az LDL-C-szint jóval 1,8 mmol/l alá való csökkentése további kockázatcsökkenést eredményez, így az LDL-C-szint célértékének leszögezése helyett annak minél nagyobb mértékü csökkentésére kellene törekedni [11]. A randomizált vizsgálatok post-hoc analízise is arra utalt, hogy a statinterápia hatékonyságában az LDL-C-szint csökkenésének mértéke a meghatározó (legalább 50\%), a célérték (1,8 mmol/l) elérésén túl [28]. Az ezetimibbel a 2002-ben történt bevezetése óta számos vizsgálatot végeztek, ezek közül a fentebb részletezett IMPROVE-IT hozott értékes evidenciákat: a szer hatékonyan csökkenti a cardiovascularis rizikót, 21\%-kal csökkentve az ischaemiás stroke bekövetkeztének esélyét is [27]. Az 50\% feletti LDL-C-szint-csökkenést, emellett az ezetimib hatékonyságát támasztotta alá a coronariaplakk-regresszióban több vascularis ultrahanggal elvégzett vizsgálat is $[29,30]$.

A közelmúltban lezárult vizsgálatok, köztük az IMPROVE-IT, új, jól megalapozott evidenciákat szolgáltatnak a lipidcsökkentő terápiás stratégiát illetően. A bővülő evidenciák, az ezzel párhuzamosan gyarapodó klinikai tapasztalat, valamint a szakmai igények a korábbi irányelvek (ESC/EAS 2013, AHA 2014) megváltoztatását vonták maguk után. Az új európai irányelvek (ESC/ EAS 2016) már elsőként az ezetimib adását javasolják, ha a kívánt LDL-C-célérték nem érhetô el statin-monoterápiával, illetve a nagyobb statindózist rosszul toleráló betegek esetében [31]. Az LDL-C-célérték cardio- és cerebrovascularis eseményen átesett betegeknél továbbra is kevesebb mint 1,8 mmol/1, a nagy rizikójú, illetve po- 


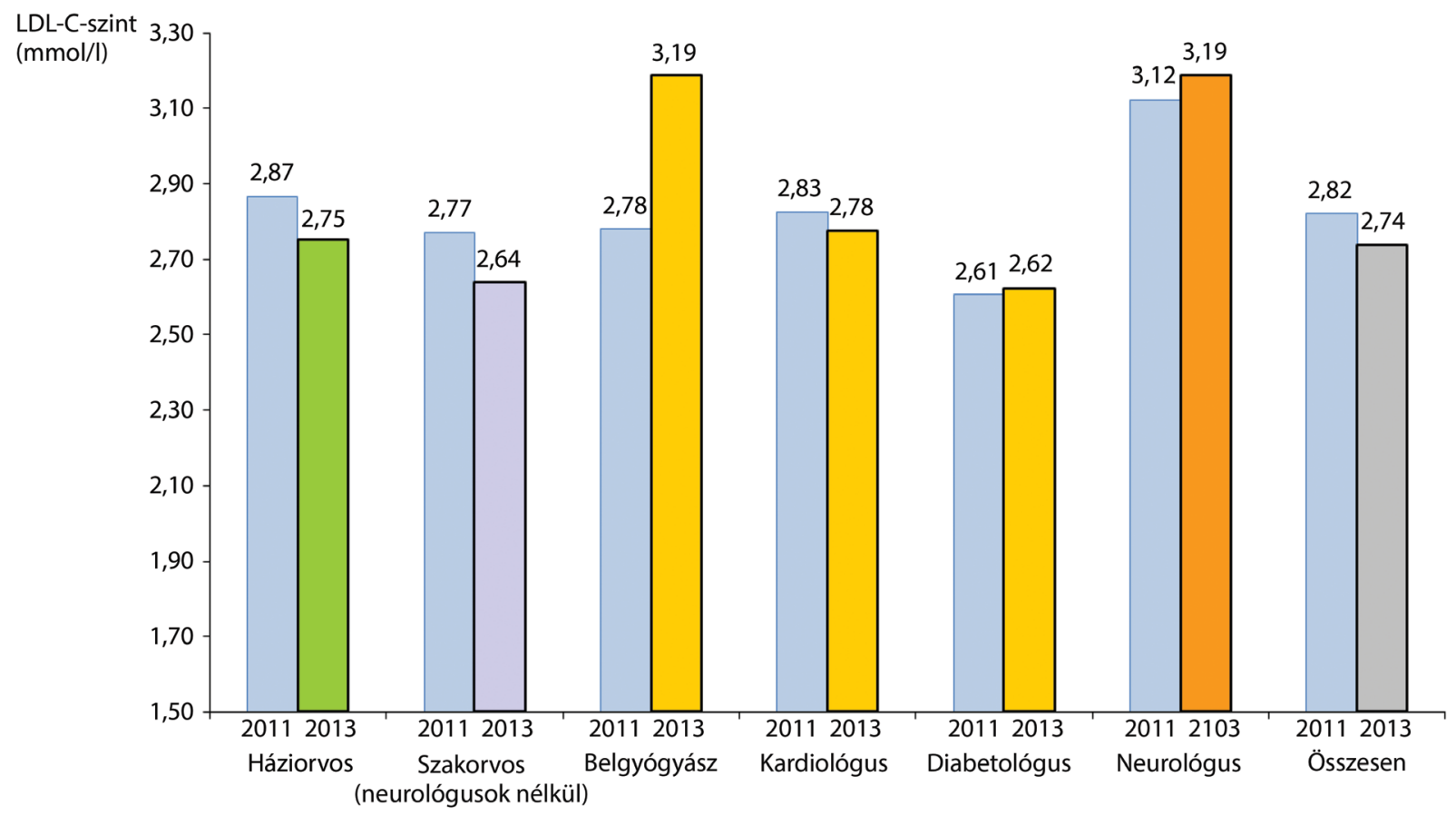

3. ábra

| Az LDL-koleszterin-értékek alakulása a kezelőorvosok szerint a 2011-es és a 2013-as MULTI GAP vizsgálatok során

zitív családi anamnézissel rendelkező betegeknél kevesebb mint 2,6 mmol/l. Egy nyolc nagy klinikai vizsgálat eredményeit kiértékelő metaanalízis rámutatott, hogy a bevont alanyok több mint 40\%-a nagy dózisú statinkezelés mellett sem érte el a kívánatos LDL-C-célértéket ( 1,8 $\mathrm{mmol} / \mathrm{l})$. Azoknál a betegeknél azonban, akiknél célérték alatti LDL-C-szintet sikerült elérni, tovább csökkent a major cardiovascularis események rizikója [32]. A statinterápiát ezetimibbel kiegészítve további 26\%-os LDL-C-szint-csökkenést érhetünk el [26], így az ezetimibet akár közepes dózisú statinhoz adva célértékre hozható a beteg, ugyanakkor a magasabb dózisú statinkezelés mellékhatásait és rizikóit (diabetes, vérzéses stroke) elkerülhetjük vagy csökkenthetjük. Ezen túlmenően az IMPROVE-IT vizsgálat és számos más tanulmány eredményei is azt támasztják alá, hogy az LDL-C-szint és a cardiovascularis rizikó közötti lineáris összefüggés körülbelül az 1,3 mmol/l szintig fennáll. Bár az ilyen alacsony LDL-C-szint megcélzásának biztonságossága még kérdéses, az eddigi eredmények ígéretesek. Mindezt figyelembe véve valószínú, hogy a jövőben az alacsonyabb célértékek eléréséhez a statinterápiát kiegészítő kezelés széles körben válhat szükségessé [33].

A lipidszintcsökkentő kezelés jelentősége a cardiovascularis prevencióban bizonyított. A statinok és az ezetimib mellett a terápiás lehetőségek bővítése segíthet abban, hogy egyre több betegnél érjünk el a célértéknek megfelelő lipidszintet. Új készítmények bevezetése természetesen csak megfelelő hatásosság és tolerálhatóság esetén lehetséges, ennek megítélésére több klinikai vizsgálat van jelenleg is folyamatban. Az új szerek közül a CETP- (koleszteril-észter transzferprotein-) gátlók Fázis 3 vizsgálataikban tapasztalt nem megfelelő hatásosságuk (dalcetrapib, evacetrapib), illetve mellékhatásaik (torcet- rapib) miatt nem kerültek elfogadásra. Negyedik képviselőjükkel, az anacetrapibbal cardiovascularis végpontú Fázis 3 vizsgálat van folyamatban, amelynek eredményei 2017-ben várhatóak. Ebben a vizsgálatban az ischaemiás stroke a másodlagos végpontok között szerepel [34]. A PCSK9 (proproteinkonvertáz szubtilizin/kexin 9) inhibitorok közül az alirokumab és az evolokumab használata az LDL-C-célérték elérésének további javítására, illetve a statint nem tolerálók körében már engedélyezett, a cardiovascularis végpontú vizsgálatok még folyamatban vannak [35]. A következő években várhatóan több, különböző támadáspontú és reményeink szerint biztonságos szerrel bővül majd a lipidszintcsökkentők családja.

\section{A statinok alkalmazása Magyarországon}

A 2013-as MULTI GAP vizsgálat (3. ábra) [36] alapján az átlagos LDL-koleszterin-értékek a 2011-es 2,82 mmol/l-ről 2013-ra 2,64 mmol/l-re csökkentek, emellett a hatékony statinokat nagyobb arányban alkalmazták. Ugyanakkor jelentős különbségek láthatók az egyes ellátási szintek között, például a háziorvosok csoportjában nagyobb az elért átlagos LDL-koleszterin-szint $(2,82 \mathrm{mmol} / \mathrm{l}), \mathrm{mint}$ a szakorvosok $(2,4-2,77 \mathrm{mmol} / \mathrm{l})$ által kezelt betegeknél. A háziorvosok után a belgyógyász és a neurológus szakorvosok által kezelt betegeknél a legnagyobb az LDL-C-szint. Az inadekvát kezelés hátterében fontos tényező lehet a nagy dózisoktól való túlzott félelem. Az ischaemiás stroke-on átesett betegek körében a hatékony prevenció egyik kulcskérdése az 1,8 mmol/l-es, illetve legalább 50\%-os LDL-C-szint-csökkenés elérése. Neurológiai szempontból a valós kockázat-nyereség arányt figyelembe véve e félelmek eltúlzottak. 


\section{Következtetések}

Az agyérbetegségek incidenciája és halálozása az LDLC-szint növekedésével párhuzamosan emelkedik, az LDL-C-szint a stroke igazolt, független kockázati tényezője. A korábbi nagy randomizált vizsgálatok és metaanalízisek alapján a statinterápia mind elsődleges, mind másodlagos prevencióként alkalmazva szignifikánsan csökkenti a stroke-kockázatot, ugyanakkor korábban egyéb lipidszintcsökkentő készítmények esetében ezt a hatást nem sikerült bizonyítani. Az IMPROVE-IT vizsgálatban elsőként sikerült bizonyítani, hogy egy nem statin típusú lipidszintcsökkentő készítményt (az ezetimibet) statinnal kombinációban adva tovább csökkenthetó a cardiovascularis események és a stroke előfordulása a statin-monoterápiához képest az igen nagy cardiovascularis rizikójú populációban. Ezek az eredmények újra megerősítették a minél nagyobb mértékű LDL-C-szintcsökkentés preventív jelentőségét. A kombináció révén a lipidcélértékek elérése alacsonyabb statindózissal is lebetséges, csökkentve a magas dózisú statinkezelés mellékhatásainak veszélyét.

Anyagi támogatás: A közlemény megjelenését az MSD Pharma Hungary Kft. tette lehetővé. A közölt információk a szerzők véleményét tükrözik, ami eltérhet az MSD Pharma Hungary Kft. álláspontjától. A megemlített termékek használatakor az érvényes alkalmazási előírás az irányadó.

Szerzői munkamegosztás: A szerzők a kézirat elkészítéséhez egyenlő mértékben járultak hozzá. A cikk végleges változatát valamennyi szerző elolvasta és jóváhagyta.

Érdekeltségek: A szerzőknek nincsenek érdekeltségeik.

\section{Irodalom}

[1] Verschuren, W. M., Jacobs, D. R., Bloemberg, B. P., et al.: Serum total cholesterol and long-term coronary heart disease mortality in different cultures. Twenty-five-year follow-up of the seven countries study. JAMA, 1995, 274(2), 131-136.

[2] Martin, M. J., Hulley, S. B., Browner, W. S., et al.: Serum cholesterol, blood pressure, and mortality: implications from a cohort of 361,662 men. Lancet, 1986, 328(8513), 933-936.

[3] Anderson, K. M., Castelli, W. P., Levy, D.: Cholesterol and mortality. 30 years of follow-up from the Framingham study. JAMA, 1987, 257(16), 2176-2180.

[4] Tirschwell, D. L., Smith, N. L., Heckbert, S. R., et al.: Association of cholesterol with stroke risk varies in stroke subtypes and patient subgroups. Neurology, 2004, 63(10), 1868-1875.

[5] Baigent, C., Keech, A., Kearney, P. M., et al.: Efficacy and safety of cholesterol-lowering treatment: prospective meta-analysis of data from 90,056 participants in 14 randomised trials of statins. Lancet, 2005, 366(9493), 1267-1278.

[6] Pedersen, T. R., Kjekshus, J., Berg, K., et al.: Randomised trial of cholesterol lowering in 4444 patients with coronary heart disease: the Scandinavian Simvastatin Survival Study (4S). 1994 Atheroscler. Suppl., 2004, 5(3), 81-87.
[7] Zhou, Q., Liao, J. K.: Pleiotropic effects of statins - Basic research and clinical perspectives. Circ. J., 2010, 74(5), 818-826.

[8] Kernan, W. N., Ovbiagele, B., Black, H. R., et al.: Guidelines for the prevention of stroke in patients with stroke and transient ischemic attack: a guideline for healthcare professionals from the American Heart Association/American Stroke Association. Stroke, 2014, 45(7), 2160-2236.

[9] Heart Protection Study Collaborative Group: MRC/BHF Heart Protection Study of cholesterol lowering with simvastatin in 20,536 high-risk individuals: a randomised placebo-controlled trial. Lancet, 2002, 360 (9326), 7-22.

[10] LaRosa, J. C., Grundy, S. M., Waters, D. D., et al., for the Treating New Targets (TNT) Investigators: Intensive lipid lowering with atorvastatin in patients with stable coronary disease. N. Engl. J. Med., 2005, 352(14), 1425-1435.

[11] Baigent, C., Blackwell, L., Emberson, J., et al.: Efficacy and safety of more intensive lowering of LDL cholesterol: a meta-analysis of data from 170,000 participants in 26 randomised trials. Lancet, 2010, 376(9753), 1670-1681

[12] Amarenco, P., Bogousslavsky, J., Callahan, A. 3rd, et al., Stroke Prevention by Aggressive Reduction in Cholesterol Levels (SPAR$C L)$ Investigators: High-dose atorvastatin after stroke or transient ischemic attack. N. Engl. J. Med., 2006, 355(6), 549-559.

[13] Jun, M., Foote, C., Lv, J., et al.: Effects of fibrates on cardiovascular outcomes: a systematic review and meta-analysis. Lancet, 2010, 375(9729), 1875-1884.

[14] Lavigne, P. M., Karas, R. H.: The current state of niacin in cardiovascular disease prevention: a systematic review and metaregression. J. Am. Coll. Cardiol., 2013, 61(4), 440-446.

[15] Kent, S., Haynes, R., Hopewell, J. C., et al.: Effects of vascular and nonvascular adverse events and of extended-release niacin with laropiprant on health and healthcare costs. Circ. Cardiovasc. Qual. Outcomes, 2016, 9(4), 348-354.

[16] Cannon, C. P., Blazing, M. A., Giugliano, R. P., et al., for the IMPROVE-IT Investigators: Ezetimibe added to statin therapy after acute coronary syndromes. N. Engl. J. Med., 2015, $372(25), 2387-2397$.

[17] Wang, W., Zhang, B.: Statins for the prevention of stroke: a metaanalysis of randomized controlled trials. PloS ONE, 2014, 9(3), e92388.

[18] Goldstein, L. B., Amarenco, P., Szarek, M., et al.: Hemorrhagic stroke in the Stroke Prevention by Aggressive Reduction in Cholesterol Levels study. Neurology, 2008, 70(24 Pt 2), 2364-2370.

[19] Ma, Y., Li, Z., Chen, L., et al.: Blood lipid levels, statin therapy and the risk of intracerebral hemorrhage. Lipids Health Dis., 2016, 15, 43 .

[20] Wang, X., Dong, Y., Qi, X., et al.: Cholesterol levels and risk of hemorrhagic stroke: a systematic review and meta-analysis. Stroke, 2013, 44(7), 1833-1839.

[21] Jimenez-Conde, J., Biffi, A., Rahman, R., et al.: Hyperlipidemia and reduced white matter hyperintensity volume in patients with ischemic stroke. Stroke, 2010, 41(3), 437-442.

[22] Meier, N., Nedeltchev, K., Brekenfeld, C., et al.: Prior statin use, intracranial hemorrhage, and outcome after intra-arterial thrombolysis for acute ischemic stroke. Stroke, 2009, 40(5), 17291737.

[23] Amarenco, P., Goldstein, L. B., Szarek, M., et al.: Effects of intense low-density lipoprotein cholesterol reduction in patients with stroke or transient ischemic attack. The Stroke Prevention by Aggressive Reduction in Cholesterol Levels (SPARCL) trial. Stroke, 2007, 38(12), 3198-3204.

[24] Zhao, D., Liu, J., Wang, W., et al.: Epidemiological transition of stroke in China: twenty-one-year observational study from the Sino-MONICA-Beijing Project. Stroke, 2008, 39(6), 16681674.

[25] Thakker, D., Nair, S., Pagada, A., et al.: Statin use and the risk of developing diabetes: a network meta-analysis. Pharmacoepidemiol. Drug Saf., 2016, 25(10), 1131-1149. 
[26] Mikbailidis, D. P., Sibbring, G. C., Ballantyne, C. M., et al.: Metaanalysis of the cholesterol-lowering effect of ezetimibe added to ongoing statin therapy. Curr. Med. Res. Opin., 2007, 23(8), 2009-2026.

[27] Bajnok, L.: The efficacy and safety of ezetimibe in the new IMPROVE-IT trial. [Az ezetimib hatásossága és biztonságossága az új IMPROVE-IT-vizsgálatban.] Metabolizmus, 2015, 13(1), 61-63. [Hungarian]

[28] Bangalore, S., Fayyad, R., Kastelein, J. J., et al.: 2013 Cholesterol guidelines revisited: Percent LDL cholesterol reduction or attained LDL cholesterol level or both for prognosis? Am. J. Med., 2016, 129(4), 384-391.

[29] Tsujita, K., Sugiyama, S., Sumida, H., et al.: Impact of dual lipidlowering strategy with ezetimibe and atorvastatin on coronary plaque regression in patients with percutaneous coronary intervention: The multicenter randomized controlled PRECISEIVUS trial. J. Am. Coll. Cardiol., 2015, 66(5), 495-507.

[30] Wang, X., Zhao X., Li, L., et al.: Effects of combination of ezetimibe and rosuvastatin on coronary artery plaque in patients with coronary heart disease. Heart Lung Circ., 2016, 25(5), 459-465.

[31] Catapano, A. L., Graham, I., De Backer, G., et al.: 2016 ESC/ EAS Guidelines for the Management of Dyslipidaemias. The Task Force for the Management of Dyslipidaemias of the European Society of Cardiology (ESC) and European Atherosclerosis
Society (EAS). Developed with the special contribution of the European Association for Cardiovascular Prevention \& Rehabilitation (EACPR). Eur. Heart J., 2016, 37(39), 2999-3058.

[32] Boekholdt, S. M., Hovingh, G. K., Mora, S., et al.: Very low levels of atherogenic lipoproteins and the risk for cardiovascular events: a meta-analysis of statin trials. J. Am. Coll. Cardiol., 2014, 64(5), 485-494.

[33] Wadhera, R. K., Steen, D. L., Khan, I., et al.: A review of lowdensity lipoprotein cholesterol, treatment strategies, and its impact on cardiovascular disease morbidity and mortality. J. Clin. Lipidol., 2016, 10(3), 472-489.

[34] Kosmas, C. E., DeJesus, E., Rosario, D., et al.: CETP inhibition: past failures and future hopes. Clin. Med. Insights Cardiol., 2016, 10, 37-42.

[35] McDonagh, M., Peterson, K., Holzhammer, B., et al.: A systematic review of PCSK9 inhibitors alirocumab and evolocumab. J. Manag. Care Spec. Pharm., 2016, 22(6), 641-653q.

[36] Simonyi, G.: Lipid-lowering therapy and patient adherence in the MULTI GAP 2013 trial. [Lipidcsökkentő terápia és betegadherencia a MULTI GAP 2013 vizsgálat tükrében.] Orv. Hetil., 2014, 155(17), 669-675. [Hungarian]

(Lovadi Emese Ildikó dr., Pécs, Maléter Pál u. 64., 7632 e-mail: lemese1987@gmail.com)

\section{Tisztelt Szerzőink, Olvasóink!}

Az Orvosi Hetilapban megjelenő/megjelent közlemények elérhetőségére több lehetőség kínálkozik.

Rendelhető különlenyomat, melynek áráról bővebben a www.akkrt.hu honlapon (Folyóirat Szerzőknek, Különlenyomat menüpont alatt) vagy Szerkesztőségünkben tájékozódhatnak.

A közlemények megvásárolhatók pdf-formátumban is, illetve igényelhető Optional Open Article (www.oopenart.com).

Adott dij ellenében az online közlemények bárki számára hozzáférhetök honlapunkon (a közlemények külön linket kapnak, így más oldalról is linkelhetővé válnak).

Bővebb információ a hirdetes@akkrt.hu címen vagy különlenyomat rendelése esetén a Szerkesztőségtöl kérhető. 